\title{
Use of a Polymer Inclusion Membrane and a Chelating Resin for the Flow-Based Sequential Determination of Copper(II) and Zinc(II) in Natural Waters and Soil Leachates
}

\author{
Tânia C. F. Ribas ${ }^{1}\left(\mathbb{D}\right.$, Charles F. Croft ${ }^{2}$, M. Inês G. S. Almeida ${ }^{2}$, Raquel B. R. Mesquita ${ }^{1}{ }^{\mathbb{D}}$, \\ Spas D. Kolev ${ }^{2}$ a and António O. S. S. Rangel ${ }^{1, * \mathbb{D}}$ \\ 1 CBQF-Centro de Biotecnologia e Química Fina-Laboratório Associado, Escola Superior de Biotecnologia, \\ Universidade Católica Portuguesa, Rua Diogo Botelho 1327, 4169-005 Porto, Portugal; \\ tpedro@porto.ucp.pt (T.C.F.R.); rmesquita@porto.ucp.pt (R.B.R.M.) \\ 2 School of Chemistry, University of Melbourne, Melbourne 3010, VIC, Australia; \\ ccroft@student.unimelb.edu.au (C.F.C.); mariads@unimelb.edu.au (M.I.G.S.A.); \\ s.kolev@unimelb.edu.au (S.D.K.) \\ * Correspondence: arangel@porto.ucp.pt
}

Received: 4 September 2020; Accepted: 5 October 2020; Published: 31 October 2020

\begin{abstract}
A bi-parametric sequential injection method for the determination of copper(II) and zinc(II) when present together in aqueous samples was developed. This was achieved by using a non-specific colorimetric reagent (4-(2-pyridylazo)resorcinol, PAR) together with two ion-exchange polymeric materials to discriminate between the two metal ions. A polymer inclusion membrane (PIM) and a chelating resin (Chelex 100) were the chosen materials to retain zinc(II) and copper(II), respectively. The influence of the flow system parameters, such as composition of the reagent solutions, flow rates and standard/sample volume, on the method sensitivity were studied. The interference of several common metal ions was assessed, and no significant interferences were observed $(<10 \%$ signal deviation). The limits of detection were 3.1 and $5.6 \mu \mathrm{g} \mathrm{L}-1$ for copper(II) and zinc(II), respectively; the dynamic working range was from 10 to $40 \mu \mathrm{g} \mathrm{L}^{-1}$ for both analytes. The newly developed sequential injection analysis (SIA) system was applied to natural waters and soil leachates, and the results were in agreement with those obtained with the reference procedure.
\end{abstract}

Keywords: bi-parametric method; sequential injection analysis; micronutrients; polymer inclusion membrane; Chelex 100

\section{Introduction}

Sample preparation is considered an essential part of the analytical process. Some of the most commonly used sample pre-treatment methods are extraction techniques, namely solid-phase extraction (SPE), liquid-liquid extraction (LLE) and, more recently, membrane-based extraction techniques, among others [1].

The basic principles of both SPE and LLE can involve adsorption, partition or ion-exchange of solutes between the two different phases. In SPE, this occurs between a liquid phase (i.e., aqueous sample) and a solid phase (e.g., sorbent material), while, in LLE, this occurs between two immiscible liquid phases [2-5]. In recent years, these techniques have been evolving towards their miniaturization (i.e., solid-phase/liquid-phase microextraction), and different types of membranes have also been used as a support for organic phase in the microextraction process [1].

Separation techniques using solid resins or liquid membrane-based materials offer good selectivity, ease of operation, low use (or no use at all) of organic solvents, low cost, fast rates of analyte extraction 
and the possibility of being reused $[2,3,6]$. These factors can be even more advantageous when these techniques are conducted in an on-line fashion as part of flow analysis methods. Therefore, these on-line separation techniques have gained high interest in the last decade [3,7].

In the present study, the strategy was to explore different polymeric materials to selectively separate copper(II) and zinc(II) and subsequently use a color reagent able to produce a similar sensitivity to the determination of both metal ions. The chromogenic reagent selected was 4-(2-pyridylazo)resorcinol (PAR). PAR is a very commonly used chromogenic chelator for the spectrophotometric determination of various metal ions [8]. This reagent was selected because it is water soluble and does not need the use of organic solvents in the preparation of its solutions, unlike some chromogenic chelating agents used for metals quantification [9].

According to previous work [9], Chelex 100 efficiently retains copper at pH of 2. Thus, Chelex 100 was the chosen resin to avoid copper(II) interference in the zinc(II) determination. Chelex 100 resin is a styrene divinylbenzene copolymer, weakly acidic due to its carboxylic acid groups, thus allowing cation exchange. This sorbent material acts as chelating resin to bind metal ions and its selectivity is closely related to the $\mathrm{pH}$ of the chelating process. Advantage was taken from this property to retain the target analyte.

For the selective detection of zinc(II), a polymer inclusion membrane (PIM) was used [6,10]. PIMs are considered as a type of liquid membranes which have attracted considerable attention in recent years [11]. These membranes are usually fabricated by casting a solution containing an extractant, a base polymer, a plasticizer (if necessary) and a volatile solvent which dissolves all PIM components. After casting and evaporation of the volatile solvent a thin, flexible and stable polymeric film is formed. PIMs have the ability to selectively separate a species of interest depending on the extractant used [6]. Kolev et al. reported a PVC-based PIM with di-(2-ethylhexyl)phosphoric acid (D2EHPA) as the extractant, capable of extracting Zn(II) selectively [12]. This PIM composition was thus chosen for the zinc(II) extraction from the sample matrix, thus enabling the copper(II) determination.

The target analytes, copper(II) and zinc(II), are important micronutrients essential for the proper functioning of living organisms, but both become toxic in high concentrations. The presence of these metal ions in ground and surface water are a direct result of using soil fertilizers or of other anthropogenic activities influencing water quality. In this scenario, it is important to monitor these metal ions in natural waters, as they act as pollution indicators. Some research has already been done for the determination of these two metal ions based on flow systems [9,13-19]. However, to accomplish both determinations with a single sequential injection analysis (SIA) system, a mathematical discrimination treatment of the experimental results had to be used [9,14-18], except for the system developed by Santos et al. [13]. A different approach is here proposed which involves the use of two on-line columns containing different ion-exchange polymeric materials for the bi-parametric determination of copper(II) and zinc(II) in natural waters and soil leachates.

\section{Results and Discussion}

\subsection{Preliminary Studies}

Two different colorimetric reagents for metal ions, namely PAR and 1-(2-pyridylazo)-2-naphthol (PAN), were initially studied via wet/bench chemistry, to determine which would be more advantageous for the spectrophotometric quantification of both $\mathrm{Cu}(\mathrm{II})$ and $\mathrm{Zn}(\mathrm{II})$. Using the same conditions for both reagents $\left(1 \mathrm{~mL}\right.$ of $0.1 \mathrm{mmol} \mathrm{L}^{-1}$ of reagent solution, $1 \mathrm{~mL}$ of $0.5 \mu \mathrm{g} \mathrm{L}^{-1}$ of metal solution and $1 \mathrm{~mL}$ of $0.6 \mathrm{mmol} \mathrm{L}^{-1}$ of carbonate buffer solution at $\mathrm{pH} 10$ ), a spectrum for each metal-reagent complex was obtained (Figure S1). By assessing the wavelength of maximum absorption of both metal complexes, it was observed that the signal was higher for the metal-PAR complexes, therefore PAR was chosen as the metal indicator to develop the SIA method. Additionally, PAR is water-soluble, which makes it easier to use. 


\subsection{Development of the SIA System}

The development of the SIA system involved a number of optimization studies to assess the influence of some chemical and physical variables on the system's analytical performance. As both complexes of PAR, with copper(II) or zinc(II) showed similar sensitivity under the same conditions (concentration of PAR, metal and buffer), copper(II) was chosen as the model analyte to conduct the optimization of the colorimetric reaction in the SIA system. The parameters assessed were the volumes of the PAR, sample and buffer solutions; the $\mathrm{pH}$ of the buffer solution; the reaction coil length; and the concentration of the PAR solution. These parameters were optimized in order to attain the highest sensitivity (calibration curve slope), the lowest reagent consumption and the most effective sampling rate.

\subsubsection{Study of the Reaction Conditions}

The first study carried out was on the PAR, sample and buffer solution volumes. Different volumes of PAR (250-350 $\mu \mathrm{L})$, buffer (10-30 $\mu \mathrm{L})$ and sample/standard (300-650 $\mu \mathrm{L})$ solutions were studied to evaluate their impact on the calibration curve parameters (Figure 1). The increase in the reagent volume resulted in an increase of the intercept $(\approx 15 \%)$ but no increase of sensitivity (calibration curve slope); thus, the lowest volume was selected to ensure minimal reagent consumption. The sensitivity increased with increasing the buffer volume up to $20 \mu \mathrm{L}$, with almost no variation in the intercept ( $<5 \%$ variation). A similar behavior was observed for the sample volume, as the sensitivity increased with the increase in the sample volume up to $550 \mu \mathrm{L}$, but in this case the intercept decreased. For higher sample volumes, the slope decreased slightly ( $\approx 10 \%$ variation) and the intercept increased slightly $(\approx 10 \%$ variation).

A)
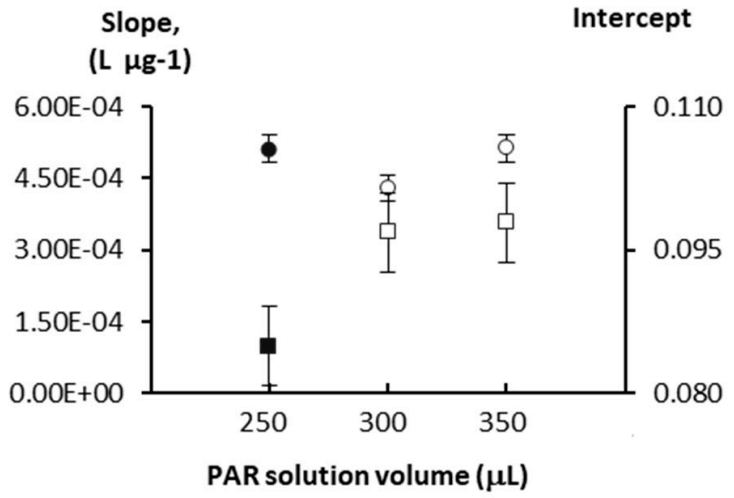

C)

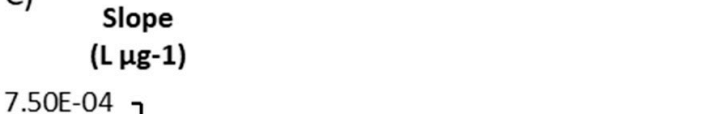

B)

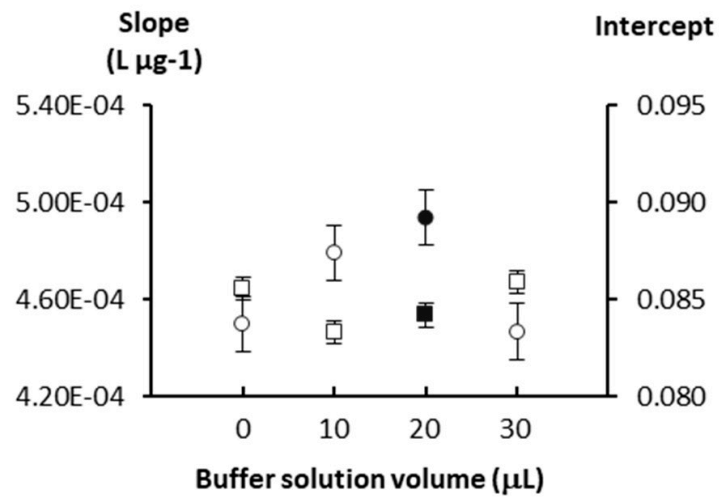

Intercept

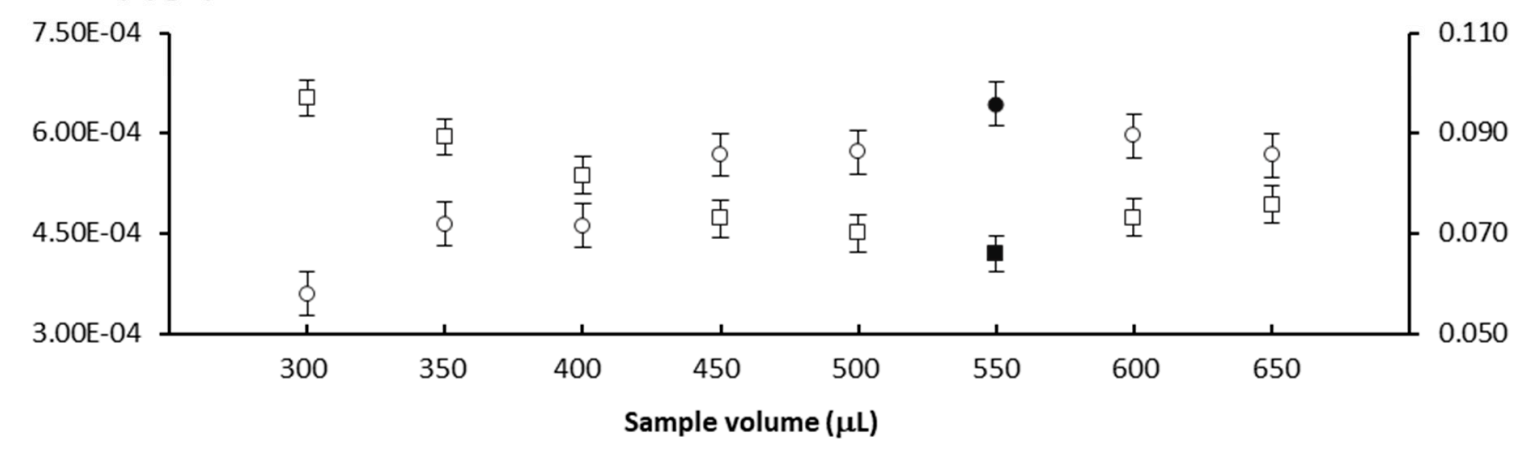

Figure 1. Study of the influence of the reagents $(\mathbf{A}, \mathbf{B})$ and sample $(\mathbf{C})$ volumes on sensitivity expressed as the calibration curve slope (circles) and on the calibration curve intercept (squares). The chosen values are represented by solid-filled markers and the error bars represent the standard error. 
The chosen volumes were $250 \mu \mathrm{L}$ for PAR, $20 \mu \mathrm{L}$ for the buffer and $550 \mu \mathrm{L}$ for the sample/standard solutions, as this combination displayed the highest slope and lowest intercept values for the calibration curve, indicating better reaction sensitivity with potentially lower detection limits for both determinations.

The reaction PTFE coil length was initially kept to a minimum $(10 \mathrm{~cm})$ allowing to physically connect the central port of the selection valve to the flow cell. As there was no significant difference $(<10 \%)$ in the absorbance signal when the coil length was increased to $20 \mathrm{~cm}$, the $10-\mathrm{cm}$ length was used in the remaining experiments.

The influence of the buffer solution composition and $\mathrm{pH}$ was studied by comparing the sensitivity obtained when using a boric acid buffer $\left(0.5 \mathrm{~mol} \mathrm{~L}^{-1}\right)$ or a carbonate buffer $\left(0.6 \mathrm{~mol} \mathrm{~L}^{-1}\right)$. Both buffer solutions were tested at two different $\mathrm{pH}$ values: 10 or 11 . No significant differences were observed ( $<5 \%$ sensitivity) between the boric acid buffer at $\mathrm{pH} 10$ and 11 and the carbonate buffers at $\mathrm{pH} 10$. However, with the use of the carbonate buffer, air bubbles were formed inside the tubing of the flow system. Additionally, when the carbonate buffer at $\mathrm{pH} 11$ was used, poor repeatability of the signal was obtained. Hence, the chosen buffer solution was the boric acid solution at $\mathrm{pH} 11$.

The influence of the PAR reagent concentration was also evaluated and the concentration of $25 \mu \mathrm{mol} \mathrm{L}-1$ was chosen from the tested values $\left(10,25,50\right.$ and $\left.100 \mu \mathrm{mol} \mathrm{L}^{-1}\right)$. When the concentration was increased above $25 \mu \mathrm{mol} \mathrm{L}^{-1}$, no significant variation $(<10 \%)$ of the calibration curve slope was observed; the chosen concentration also produced a lower intercept value.

\subsubsection{Study of the Retention of Copper(II) and Zinc(II).}

Since PAR is sensitive to both copper(II) and zinc(II), a dual-extraction approach was adopted in order to be able to determine both metal ions individually and sequentially. The strategy chosen for the selective copper(II) determination consisted of the use of a PVC-based PIM containing D2EHPA as the extractant to retain zinc(II). Some studies were conducted to maximize the on-line retention of zinc(II) in natural water samples into the PIM and consequently determine copper(II). As the PIM column was linked to one of the peripheral ports of the selection valve, direct aspiration of a standard, containing both copper(II) and zinc(II), through the column was attempted first; however, the retention was not efficient. Alternatively, with the aim to enhance the interaction between the solution and the PIM, the standard was aspirated from another port of the selection valve to the holding coil of the SIA system, subsequently propelled through the column and aspirated back to the holding coil. Using this approach, two experiments were conducted. In the first one, the standard was propelled through the PIM column, followed by the sequential aspiration of PAR reagent, buffer solution and Zn(II)-free standard into the holding coil. After flow reversal, the stack of solution zones in the holding coil were propelled towards the detector. In the second experiment, a similar procedure was adopted except that the flow was stopped for $5 \mathrm{~s}$ when the standard zone was in the PIM column. No significant difference in the maximum absorbance signals was observed between the two experiments; thus, to further improve the retention of zinc(II), the procedure involving propelling and aspirating the standard zone through the PIM column was conducted twice (Figure S2A). This retention procedure was thus the chosen approach for further optimization.

According to Paluch et al. [9], copper(II) can be retained in a column packed with Chelex 100 resin at $\mathrm{pH}$ of 2 . Hence, for the selective zinc(II) determination, this was the strategy chosen to eliminate the interference of copper(II). A packed column was linked to one of the peripheral ports of the selection valve, through which the standard/sample was directly aspirated towards the holding coil, thus retaining any copper(II) present in the original standard/sample (Figure S2B).

\subsection{Interference Studies}

Being a non-specific chromogenic reagent, PAR forms an orange complex with a variety of different metal ions and, thus, the potential interference from other metal ions was assessed. The ions that can be present in natural water samples and thus interfere with the proposed analytical method are described 
in Table 1. The selected concentrations for each ion corresponded to the maximum concentration that can be expected in environmental waters [20]. The obtained absorbance of a standard with and without the possible interfering ion was measured and the interference percentage calculated (Table 1).

Table 1. Interference study of metal ions $\left(\left[\mathrm{M}^{\mathrm{n}+}\right]\right)$ commonly present in environmental waters at their maximum expected concentrations $\left(\left[\mathrm{M}^{\mathrm{n}+}\right]_{\max }\right)[20]$. SD, Standard deviation $(\mathrm{n}=3)$.

\begin{tabular}{|c|c|c|c|c|c|c|}
\hline Tested Ion & $\begin{array}{l}{\left[\mathrm{M}^{\mathrm{n}+}\right]_{\max } \text { in }} \\
\text { Streams, } \\
\mu \mathrm{g} \mathrm{L}^{-1}\end{array}$ & $\begin{array}{l}\text { Tested } \\
{\left[\mathbf{M}^{\mathrm{n}+}\right]} \\
\mu \mathrm{g} \mathrm{L}^{-1}\end{array}$ & $\begin{array}{l}\text { Interference in } \\
\mathrm{Cu}(\mathrm{II}) \\
\text { Determination, } \\
\%\end{array}$ & SD & $\begin{array}{l}\text { Interference in } \\
\text { Zn(II) } \\
\text { Determination, } \\
\%\end{array}$ & SD \\
\hline $\mathrm{Al}^{3+}$ & 400 & 400 & -1.0 & 1.0 & -1.3 & 0.9 \\
\hline $\mathrm{Ca}^{2+}$ & 15000 & 15000 & 1.0 & 1.0 & -3.6 & 2.0 \\
\hline $\mathrm{Co}^{2+}$ & 0.2 & 10 & 1.6 & 0.1 & 1.5 & 0.1 \\
\hline $\mathrm{Cu}^{2+}$ & $<12$ & 40 & - & - & 2.5 & 0.7 \\
\hline \multirow{2}{*}{$\mathrm{Fe}^{3+}$} & \multirow{2}{*}{700} & 400 & 14.9 & 2.8 & 8.5 & 0.3 \\
\hline & & 200 & 8.2 & 1.3 & - & - \\
\hline \multirow{2}{*}{$\mathrm{Mg}^{2+}$} & \multirow{2}{*}{4000} & 5000 & 3.1 & 2.6 & 35.8 & 5.8 \\
\hline & & 2500 & - & - & -4.3 & 3.0 \\
\hline $\mathrm{Mn}^{2+}$ & 7 & 50 & 4.3 & 3.0 & 1.4 & 0.3 \\
\hline $\mathrm{Ni}^{2+}$ & 1 & 50 & 4.5 & 1.8 & 1.2 & 0.4 \\
\hline $\mathrm{Zn}^{2+}$ & 20 & 40 & 5.1 & 2.1 & - & - \\
\hline
\end{tabular}

The only interferences above $10 \%$ were from iron(III) and magnesium(II); however, values above $400 \mu \mathrm{g} \mathrm{L}^{-1} \mathrm{Fe}(\mathrm{III})$ are not usually found in environmental waters, and the tested magnesium concentration was above the expected values. The interference from iron(III) has been previous reported and could be eliminated by precipitation with phosphate prior to the analysis [12].

\subsection{Features}

The features of the newly developed SIA method for the bi-parametric determination of copper(II) and zinc(II) are summarized in Table 2.

Table 2. Calibration curves and dynamic concentration ranges for copper(II) and zinc(II) and their respective limits of detection (LOD). A, absorbance; $\mathrm{SD}$, standard deviation; $\mathrm{M}^{2+}$, metal ion.

\begin{tabular}{lllll}
\hline Metal Ion & $\begin{array}{l}\text { Dynamic Range } \\
\left(\mu \mathbf{~ L ~}^{-\mathbf{1}}\right)\end{array}$ & $\begin{array}{l}\text { Calibration Curve } \\
\mathbf{A}=\left(\text { Slope } \pm \text { SD) }\left[\mathbf{M}^{2+}\right]+\text { Intercept } \pm \text { SD }\right.\end{array}$ & $\begin{array}{l}\text { LOD } \\
\left(\mu \mathbf{g ~ L}^{-1}\right)\end{array}$ & RSD (\%) \\
\hline Copper(II) & $10.0-40.0$ & $\begin{array}{l}\mathrm{A}=\left(9.00 \times 10^{-4} \pm 1.00 \times 10^{-4}\right)\left[\mathrm{Cu}^{2+}\right]+ \\
0.112 \pm 0.007\end{array}$ & 3.1 & 2.0 \\
Zinc(II) & $10.0-40.0$ & $\begin{array}{l}\mathrm{A}=\left(1.80 \times 10^{-3} \pm 1.0 \times 10^{-4}\right)\left[\mathrm{Zn}^{2+}\right]+ \\
0.099 \pm 0.003\end{array}$ & 5.6 & 1.3 \\
\hline
\end{tabular}

$\mathrm{RSD}$, relative standard deviation; ${ }^{\mathrm{a}} \mathrm{n}=3$.

The limits of detection were calculated according to the IUPAC recommendations as the concentration corresponding to the sum of three times the standard deviation to the mean value of ten consecutive blank solution measurements [21,22].

The relative standard deviation (RSD) for $\mathrm{Cu}(\mathrm{II})$ and $\mathrm{Zn}$ (II) determination was calculated with twelve replicate analysis (four consecutive cycles) of a standard with $20 \mu \mathrm{g} \mathrm{L} \mathrm{L}^{-1}$ of each metal ion.

A complete cycle, which includes three replicates for each determination and the washing of the PIM column at the end, has the duration of $10 \mathrm{~min}$. The corresponding PAR, sodium hydroxide and boric acid consumption per cycle is $8.1 \mu \mathrm{g}, 1.4 \mathrm{mg}$ and $5.6 \mathrm{mg}$, respectively. 


\subsection{Application to Natural Water and Soil Leachate Samples-Validation of the Method}

The newly developed SIA system for the determination of copper(II) and zinc(II) was applied to river water samples (S1-S9) and soil leachates (S10-S14). The validation was attained by comparison of the results obtained with the newly developed SIA method with those obtained by the reference procedure (ICP-OES) (Table 3).

A linear relationship was established between the copper(II) and zinc(II) concentrations determined by the newly developed SIA system $\left(\mathrm{C}_{\text {SIA }}\left(\mu \mathrm{g} \mathrm{L} \mathrm{L}^{-1}\right)\right)$ and the reference procedure $\left(\mathrm{C}_{\mathrm{ICP}}\left(\mu \mathrm{g} \mathrm{L}{ }^{-1}\right)\right)$ (Figure S3). The linear regression for the copper(II) determination was $\mathrm{C}_{\text {SIA }}=1.05( \pm 0.10)$ and $\mathrm{C}_{\mathrm{ICP}}=2.63( \pm 10.99)$, where the values in brackets represent the $95 \%$ confidence interval.

The linear regression for the zinc(II) determination was $\mathrm{C}_{\mathrm{SIA}}=1.03( \pm 0.02)$ and $\mathrm{C}_{\mathrm{ICP}}=0.46( \pm 2.53)$, where the values in brackets represent the $95 \%$ confidence interval. These data show that the estimated slope and intercept do not differ statistically from 1 and 0 , respectively [23]. In addition, the relative deviation between the two sets of results proved that there were no significant differences between the newly developed SIA method and the reference procedure, $\mathrm{RD} \leq 10 \%$ (Table 3).

The accuracy of the newly developed SIA method was evaluated by analyzing a certified reference water sample (ERM CA011-hard drinking water-metals) with $1963 \pm 62$ and $605 \pm 17 \mu \mathrm{g} \mathrm{L}^{-1}$ of copper(II) and zinc(II), respectively. The concentration values obtained with the newly developed SIA system were $1789 \pm 61$ and $609 \pm 24 \mu \mathrm{g} \mathrm{L}^{-1}$ for copper(II) and zinc(II), respectively, corresponding to relative deviations of $-8.9 \%$ and $+0.7 \%$. These results indicate that the newly developed SIA system offered acceptable accuracy. 
Table 3. Comparison of the results obtained with the newly developed SIA system for copper(II) and zinc(II) determination (three replicates) with those obtained with ICP-OES (two replicates). S1-S9, river water samples; S10-S14, soil leachate samples; SD, standard deviation; RD, Relative deviation.

\begin{tabular}{|c|c|c|c|c|c|c|c|c|c|c|}
\hline Sample ID & $\begin{array}{l}\text { Copper(II) } \\
\text { SIA } \\
{\left[\mathrm{Cu}^{2+}\right] \mu \mathrm{g} \mathrm{L}^{-1}}\end{array}$ & SD & $\begin{array}{l}\mathrm{ICP} \\
{\left[\mathrm{Cu}^{2+}\right] \mu \mathrm{g} \mathrm{L}^{-1}}\end{array}$ & SD & RD \% & $\begin{array}{l}\operatorname{Zinc}(\mathrm{II}) \\
\text { SIA } \\
{\left[\mathrm{Zn}^{2+}\right] \mu \mathrm{g} \mathrm{L}^{-1}}\end{array}$ & $\begin{array}{l}\text { ICP } \\
\text { SD }\end{array}$ & {$\left[\mathrm{Zn}^{2+}\right] \mu \mathrm{g} \mathrm{L}^{-1}$} & SD & RD \% \\
\hline $\mathrm{S} 1$ * & 14.9 & 1.2 & 14.3 & 0.1 & +3.7 & 22.8 & 2.4 & 21.6 & 0.3 & +5.4 \\
\hline $\mathrm{S} 2$ * & 19.5 & 2.6 & 20.6 & 0.3 & -5.8 & 20.1 & 0.9 & 19.3 & 0.3 & +3.9 \\
\hline S3 * & 22.8 & 1.8 & 20.8 & 0.3 & +6.4 & 31.4 & 3.0 & 33.5 & 0.4 & -6.5 \\
\hline S4 & 197 & 8 & 183 & 3 & +7.6 & $<\mathrm{LOD}$ & - & $<\mathrm{LOD}$ & - & - \\
\hline S5 & 140 & 8 & 143 & 2 & -2.3 & $<$ LOD & - & $<\mathrm{LOD}$ & - & - \\
\hline S6 & 107 & 5 & 114 & 2 & -6.4 & $<\mathrm{LOD}$ & - & $<\mathrm{LOD}$ & - & - \\
\hline S7 & 72.2 & 4.1 & 74 & 3 & -2.4 & $<\mathrm{LOD}$ & - & $<\mathrm{LOD}$ & - & - \\
\hline S8 & 156 & 10 & 143 & 5 & +9.3 & $<\mathrm{LOD}$ & - & $<\mathrm{LOD}$ & - & - \\
\hline S9 & $<\mathrm{LOD}$ & - & $<\mathrm{LOD}$ & - & - & $<\mathrm{LOD}$ & - & $<\mathrm{LOD}$ & - & - \\
\hline S10 & $<$ LOD & - & 2.08 & 0.1 & - & 15.2 & 2.0 & 14.9 & 0.2 & +2.0 \\
\hline S11 & $<$ LOD & - & 2.71 & 0.1 & - & 14.3 & 1.6 & 14.6 & 0.3 & -2.0 \\
\hline S12 & $<\mathrm{LOD}$ & - & $<\mathrm{LOD}$ & - & - & 340 & 12 & 332 & 3 & +2.5 \\
\hline S13 & $<\mathrm{LOD}$ & - & $<\mathrm{LOD}$ & - & - & 32.9 & 3.5 & 33.2 & 0.3 & -0.9 \\
\hline S14 & $<$ LOD & - & 0.58 & 0.1 & - & 203 & 3 & 193 & 3 & +4.9 \\
\hline
\end{tabular}




\section{Materials and Methods}

\subsection{Reagents and Solutions}

All solutions were prepared with analytical grade chemicals and MilliQ water (resistivity $>18 \mathrm{M} \Omega \mathrm{cm}$, Millipore, Burlington, MA, USA).

A stock solution of $50.0 \mathrm{mg} \mathrm{L}^{-1}$ of copper(II) and zinc(II) were prepared by dilution of the respective $1000 \mathrm{mg} \mathrm{L}^{-1}$ atomic absorption standard solutions (Spectrosol, Poole, England). An intermediate solution of $500 \mu \mathrm{g} \mathrm{L}^{-1}$ of each metal solution was prepared by dilution of a $50.0 \mathrm{mg} \mathrm{L}^{-1}$ stock solution. Working standards, in the range $10-40 \mu \mathrm{g} \mathrm{L}^{-1}$ in $0.01 \mathrm{~mol} \mathrm{~L}^{-1}$ of nitric acid, were prepared weekly by dilution of a $500 \mu \mathrm{g} \mathrm{L}^{-1}$ intermediate solution with a $0.01 \mathrm{~mol} \mathrm{~L}^{-1}$ nitric acid solution.

A $0.01 \mathrm{~mol} \mathrm{~L}^{-1}$ nitric acid solution was prepared by dilution of the commercial concentrated nitric acid solution ( $\mathrm{d}=1.39 ; 65 \%$, Merck; Darmstadt, Germany).

A buffer solution of $0.50 \mathrm{~mol} \mathrm{~L}{ }^{-1}$ boric acid was prepared by dissolution of the solid $\left(\mathrm{H}_{3} \mathrm{BO}_{3}\right.$, Aldrich, Germany) in a solution of $0.2 \mathrm{~mol} \mathrm{~L}^{-1} \mathrm{NaOH}$ (Panreac, Chicago, IL, USA), with the final $\mathrm{pH}$ adjusted to 11.0 with a sodium hydroxide solution.

A $2 \mathrm{mmol} \mathrm{L}^{-1}$ stock solution of PAR $\left(\mathrm{C}_{11} \mathrm{H}_{8} \mathrm{~N}_{3} \mathrm{NaO}_{2} \cdot \mathrm{H}_{2} \mathrm{O}\right.$, Sigma-Aldrich, St Louis, MO, USA) was prepared by dissolving the corresponding quantity of the monosodium salt hydrate in water. A PAR reagent solution of $25 \mu \mathrm{mol} \mathrm{L}{ }^{-1}$ was prepared weekly by dilution of the stock solution with MilliQ water.

\subsection{Preparation of the PIM Column}

PIMs were produced by dissolving a mixture of $8.25 \mathrm{~g}$ of PVC and $6.75 \mathrm{~g}$ of D2EHPA in $165 \mathrm{~mL}$ of tetrahydrofuran (THF). Approximately $2.75 \mathrm{~mL}$ of this solution was cast into a glass ring with a 76-mm diameter which was positioned on a flat glass plate. All rings were covered with filter paper, a glass plate and a foil tray to control the evaporation of THF that was completed within a period of 48-72 h. The resulting PIM composition was $45 \mathrm{wt} \%$ D2EHPA and $55 \mathrm{wt} \%$ PVC.

PIMs were subsequently cut into strips of approximately $2 \mathrm{~mm}$ in width. A laboratory made column (5.5 cm length of Versilon 2001 tubing with $4.8 \mathrm{~mm}$ i.d.) was packed with the PIM stripes (approximately $100 \mathrm{mg}$ ) between two female Luer Tefzel connectors (P-624; Thermo Scientific, Waltham, MA, USA). The column was connected to one of the ports of the selection valve of the SIA system utilized in this study and subsequently used for zinc(II) retention.

Two columns were prepared and used along the method development and application to the sample analyses. This occurred for about four months for each column, without noticing significant deterioration on their performance.

\subsection{Preparation of the Chelex 100 Column}

A laboratory made column with $25 \mathrm{~mm}$ in length of Tygon tubing (Gilson, Villiers-le-Bel, France) with $1.85 \mathrm{~mm}$ i.d. and $67 \mu \mathrm{L}$ inner volume was used to pack the chelating resin. Approximately $75 \mathrm{mg}$ of Chelex 100 (mesh 200-400, Bio-Rad, Hercules, CA, USA), previously suspended in water, was introduced into the column between two pieces of dishwashing sponge. The column was connected to one of the ports of the SIA selection valve and used for copper retention.

One column was prepared and used throughout the entire method development, corresponding to approximately eight months, displaying a consistent performance.

\subsection{Apparatus}

Solutions were propelled in the experimental SIA system (Figure 2) by a syringe pump with a $5 \mathrm{~mL}$ barrel (Crison, Barcelona, Spain). The pump was connected to the central channel of a ten-port electrically actuated selection valve (Valco VICI Cheminert C25-3180D 06B-0699C, Houston, TX, USA) with a polytetrafluoroethylene (PTFE) tubing. PTFE tubing (0.8 mm i.d., Omnifit, Cambridge, UK) connected all the components of the SIA system. The syringe pump and the selection valve 
were controlled by AutoAnalysis Station 5.0 computer software (Sciware, Balearic Islands, Spain). As detection system consisted of an Ocean Optics (Orlando, FL, USA) USB 4000 charged coupled device detector (CCD) equipped with a pair of $600 \mathrm{~mm}$ optical cables, a Mikropack DH-2000-BAL deuterium halogen light source and an Ultem ${ }^{\circledR}$ flow cell (SMA-Z-50 cell) with 50-mm optical path (130 $\mu \mathrm{L}$ inner volume).

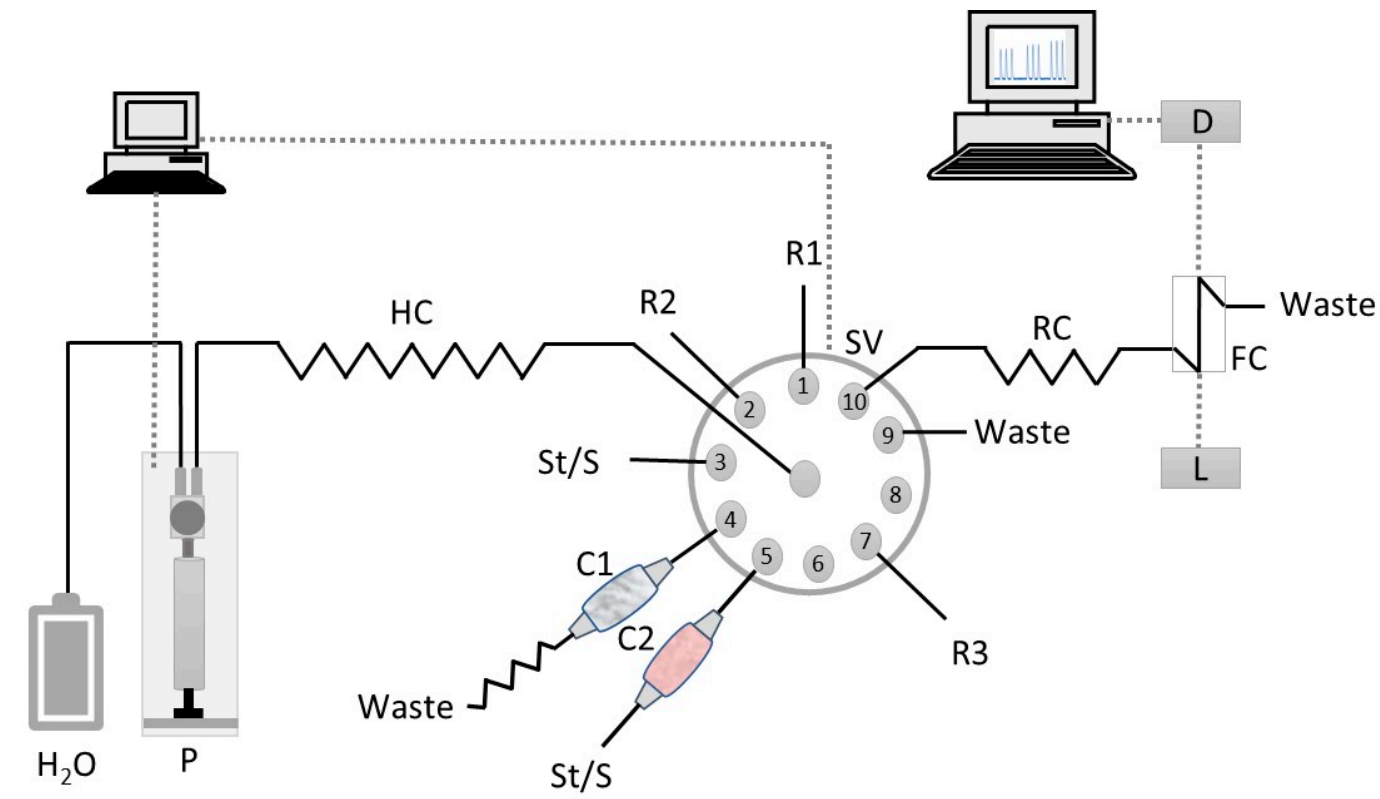

Figure 2. Flow manifold for $\mathrm{Cu}(\mathrm{II})$ and $\mathrm{Zn}(\mathrm{II})$ determination in waters and soil leachates. St/S, standard solution or sample; R1, PAR reagent $\left(25 \mu \mathrm{mol} \mathrm{L}^{-1}\right)$; R2, boric acid buffer solution (pH 11); R3- nitric acid solution ( $0.5 \mathrm{~mol} \mathrm{~L}^{-1}$ ); C1, PIM column; C2, Chelex 100 resin column; P, syringe pump; SV, selection valve; HC, holding coil (300 cm); RC, reaction coil $(10 \mathrm{~cm})$; D, CCD detector; L, light source; FC, Z flow cell (50-mm path length); W, waste.

\subsection{Flow Manifold and Procedure}

The sequence of steps for the determination of copper(II) and zinc(II) is shown in Table 4. It was divided in two parts, one corresponding to the $\mathrm{Zn}$ (II) determination using solid-phase extraction for the removal of $\mathrm{Cu}$ (II) and the other to the $\mathrm{Cu}$ (II) determination using PIM-based extraction to retain $\mathrm{Zn}(\mathrm{II})$. For the Zn(II) determination (Steps A-D, Table 4), reagent (Port 1, Figure 2), buffer (Port 2) and sample/standard (Port 5) were sequentially aspirated into the holding coil (HC). The sample/standard was aspirated through the Chelex 100 column (C2) via Port 5 . Then, the staked zones were propelled to the flow cell (FC) where the absorbance was continuously monitored at $490 \mathrm{~nm}$ corresponding to the absorption maximum of the $\mathrm{Zn}$ (II)-PAR colored complex. For the $\mathrm{Cu}$ (II) determination (Steps E-M, Table 4), sample/standard was aspirated to the holding coil via Port 3, and then propelled through the PIM column (C1) to eliminate possible Zn(II) interference (Steps E and F). After passing through the PIM column, the flow was reversed twice to promote $\mathrm{Zn}(\mathrm{II})$ retention. After this procedure, reagent (Port 1), buffer (Port 2) and the Zn(II) free sample/standard (Port 1) were aspirated into the holding coil (HC). Then, these three zones were propelled to the flow cell (FC) for absorbance measurement of the $\mathrm{Cu}(\mathrm{II})-\mathrm{PAR}$ colored complex at $490 \mathrm{~nm}$. 
Table 4. Experimental protocol for the copper(II) and zinc(II) determination.

\begin{tabular}{|c|c|c|c|c|}
\hline Step & $\begin{array}{l}\text { Selection Valve } \\
\text { Position }\end{array}$ & $\begin{array}{l}\text { Volume } \\
(\mathrm{mL})\end{array}$ & $\begin{array}{l}\text { Flow-Rate } \\
\left(\mathrm{mL} \min ^{-1}\right)\end{array}$ & Description \\
\hline \multicolumn{2}{|c|}{$\begin{array}{l}\text { Preliminary steps before } \\
\text { starting consecutive cycles }\end{array}$} & $\begin{array}{l}5.000 \\
1.000\end{array}$ & - & $\begin{array}{l}\text { Syringe reset position-syringe filled with carrier } \\
\text { Propel carrier (water) to waste }\end{array}$ \\
\hline A & 1 & 0.250 & 3.529 & Aspirate PAR solution \\
\hline B & 2 & 0.020 & 3.529 & Aspirate boric acid buffer solution \\
\hline C & 5 & 0.550 & 2.000 & $\begin{array}{l}\text { Aspirate standard/sample through the Chelex } 100 \\
\text { column to eliminate } \mathrm{Cu} \text { (II) interference }\end{array}$ \\
\hline \multirow[t]{2}{*}{$\mathrm{D}$} & 10 & 2.100 & 3.529 & $\begin{array}{l}\text { Propel through the spectrometer flow cell for } \mathrm{Zn} \text { (II) } \\
\text { quantification }\end{array}$ \\
\hline & & & & Fill the syringe with carrier \\
\hline E & 3 & 0.550 & 2.000 & Aspirate standard/sample \\
\hline $\mathrm{F}$ & 4 & 0.600 & 2.000 & $\begin{array}{l}\text { Propel through the PIM column to eliminate } \mathrm{Zn}(\mathrm{II}) \\
\text { interference by retaining } \mathrm{Zn}(\mathrm{II})\end{array}$ \\
\hline G & 4 & 0.250 & 2.000 & $\begin{array}{l}\text { Aspirate standard/sample through the PIM column } \\
\text { to promote retention of } \mathrm{Zn}(\mathrm{II})\end{array}$ \\
\hline $\mathrm{H}$ & 4 & 0.250 & 2.000 & $\begin{array}{l}\text { Propel standard/sample through the PIM column to } \\
\text { promote retention of } \mathrm{Zn}(\mathrm{II})\end{array}$ \\
\hline I & 9 & 0.250 & 3.529 & Dispense to waste the left residues in the holding coil \\
\hline $\mathrm{J}$ & 1 & 0.250 & 3.529 & Aspirate PAR solution \\
\hline K & 2 & 0.020 & 3.529 & Aspirate boric acid buffer solution \\
\hline $\mathrm{L}$ & 4 & 0.550 & 2.000 & Aspirate $\mathrm{Zn}(\mathrm{II})$ free standard/sample solution \\
\hline \multirow[t]{2}{*}{ M } & 10 & 2.100 & 3.529 & $\begin{array}{l}\text { Propel through the spectrometer flow cell for } \mathrm{Cu}(\mathrm{II}) \\
\text { quantification }\end{array}$ \\
\hline & & & & Fill the syringe with carrier \\
\hline $\mathrm{R}$ & 7 & 0.500 & 5.000 & Aspirate $\mathrm{HNO}_{3}$ solution \\
\hline S & 4 & 1.500 & 5.000 & Propel through the PIM column—cleaning step \\
\hline
\end{tabular}

At the end of the cycle, the PIM column was washed and reconditioned with $0.5 \mathrm{~mol} \mathrm{~L}^{-1}$ nitric acid (Port R3) and ultrapure water (carrier solution), sequentially.

Each absorbance value was calculated as the difference between the absorbances at $490 \mathrm{~nm}$ (wavelength of maximum absorption) and $800 \mathrm{~nm}$; this subtraction aimed at minimizing the schlieren effect [24].

\subsection{Sample Collection and Preparation}

\subsubsection{Water Samples}

River water samples (S1-S9) from various locations in the Porto area were collected, filtered (Acrodisc $25 \mathrm{~mm}$ syringe filters, $0.45 \mu \mathrm{m}$, Pall, USA) and acidified to $\mathrm{pH} 2$ with nitric acid, according to the reference procedure [20]. Samples were kept refrigerated at $4{ }^{\circ} \mathrm{C}$ until analysis.

When copper(II) concentration was above $40 \mu \mathrm{g} \mathrm{L}^{-1}$, the water samples were diluted in order to fit the respective linear working range. In some samples, the zinc(II) concentration was below the detection limit, in which case the samples were spiked with zinc(II) (samples S1-S3).

\subsubsection{Soil Leachates Samples}

The soil samples were collected in the northwest of Portugal using an acrylic cylinder that was pushed into the ground to collect a superficial soil core (about $20 \mathrm{~cm}$ depth). Two soil cores were collected. A commercial fertilizer was applied to the soil columns following the manufactured instructions.

To simulate the soil leaching process naturally occurring in the field, rain simulations were performed by passing $50 \mathrm{~mL}$ of previously collected rainwater $\left(\mathrm{pH} \approx 6.6\right.$; conductivity $\approx 8.4 \mu \mathrm{S} \mathrm{cm}{ }^{-1}$ ) through each soil core. Both the collected rainwater and the obtained leachates were filtered (Acrodisc $25 \mathrm{~mm}$ syringe filters, $0.45 \mu \mathrm{m}$, Pall, New York, NY, USA) and acidified to $\mathrm{pH} 2$ with nitric acid.

Several simulations of rain were performed (for 5 consecutive days) and the soil leachates were collected. Samples were kept refrigerated until analysis. The soil leachates samples (S9-S14) were 
diluted when zinc(II) concentrations were above $40 \mu \mathrm{g} \mathrm{L}^{-1}$, in order to fit in the linear range of the zinc(II) calibration.

\subsection{Reference Procedure}

For validation purposes, the determinations of $\mathrm{Cu}(\mathrm{II})$ and $\mathrm{Zn}(\mathrm{II})$ in soil leachates and natural waters were carried out by inductively coupled plasma-optical emission spectrometry, ICP-OES (Perkin Elmer Optima $7000 \mathrm{dv}$, USA), and the results were compared with those obtained with the newly developed SIA method.

Additionally, the SIA system developed for the quantification of $\mathrm{Cu}(\mathrm{II})$ and $\mathrm{Zn}$ (II) was applied to the analysis of a certified water sample, ERM-CA011 (hard drinking water, LGC, Teddington, UK). The certified water sample was diluted in a multi-step fashion so that its concentration would fit within the linear range of the corresponding calibration curves.

\section{Conclusions}

With the aim of directly and individually quantifying copper(II) and zinc(II) with the same color reagent, two polymeric materials, namely a PIM and Chelex 100, packed in columns, were efficiently used. To the authors best knowledge, this was the first time that a PIM was used with this objective of on-line retaining and eliminating interferences from a sample. PVC-based PIMs containing D2EHPA proved to be efficient in retaining zinc(II), allowing for the quantification of copper(II). Chelex 100 was the polymeric material used to retain copper(II) at pH 2.0, as has already been reported in previous studies [9]. Zinc(II) was not retained at this $\mathrm{pH}$, thus allowing for its quantification to be performed free of copper(II) interference.

Some flow-based methodologies have been previously developed [9,13,14,16-19] for the determination of these two metals in water samples using various chromogenic reagents (Table 5). Unlike these methods, the newly developed SIA system can determine copper(II) and zinc(II) individually and directly using a single manifold with the use of a single colorimetric reaction (PAR-Metal), thus reducing the time required per analysis while offering similar and in some cases better sensitivity. For example, the Zincon-Metal approach does not allow individual determination of the two metal ions [14,16-18].

Table 5. Analytical features of flow-based systems developed for copper(II) and zinc(II) spectrophotometric determination in water samples (presented in descending chronological order).

\begin{tabular}{|c|c|c|c|c|c|c|c|}
\hline System & Sample & $\begin{array}{c}\text { Sample } \\
\text { Volume } \\
(\mu \mathrm{L})\end{array}$ & SPE & Reagent & $\begin{array}{c}\text { Sample } \\
\text { Throughput } \\
\left(h^{-1}\right)\end{array}$ & $\begin{array}{c}\text { LOD } \\
\left(\mu \mathrm{g} \mathrm{L}^{-1}\right)\end{array}$ & Ref. \\
\hline SIA & $\begin{array}{l}\text { Natural } \\
\text { waters }\end{array}$ & 550 & $\begin{array}{c}\text { PIM and } \\
\text { Chelex } 100\end{array}$ & PAR & 6 & $\begin{array}{l}\mathrm{Cu}, 3.1 \\
\mathrm{Zn}, 5.6\end{array}$ & This work \\
\hline SIA & $\begin{array}{c}\text { Water and soil } \\
\text { leachates }\end{array}$ & 413 & Chelex 100 & PAN & 3 & $\begin{array}{l}\mathrm{Cu}, 3.0 \\
\mathrm{Zn}, 1.4\end{array}$ & [9] \\
\hline$\mu$ SI-LOV & Freshwaters & 600 & NTA & Dithizone & $\begin{array}{l}\mathrm{Cu}, 15 \\
\mathrm{Zn}, 13\end{array}$ & $\begin{array}{l}\mathrm{Cu}, 0.11 \\
\mathrm{Zn}, 2.39\end{array}$ & [13] \\
\hline SIC & Water & 90 & - & PAR & 9 & $\begin{array}{l}\mathrm{Cu}, 13 \\
\mathrm{Zn}, 13\end{array}$ & [19] \\
\hline MSFIA & Waters & 400 & - & Zincon & 43 & $\begin{array}{c}\mathrm{Cu}, 0.1 \\
\mathrm{Zn}, 2\end{array}$ & [14] \\
\hline SIA & Water samples & 150 & - & Zincon & 36 & $\begin{array}{l}\mathrm{Cu}, 48 \\
\mathrm{Zn}, 13\end{array}$ & [17] \\
\hline BIS-FIA & $\begin{array}{c}\text { Waters, } \\
\text { pharmaceuticals } \\
\text { and soils }\end{array}$ & 1000 & $\begin{array}{l}\text { Sephadex } \\
\text { QAE A-25 }\end{array}$ & Zincon & 15 & $\begin{array}{l}\mathrm{Cu}, 29 \\
\mathrm{Zn}, 40\end{array}$ & [16] \\
\hline FIA & $\begin{array}{l}\text { Water and } \\
\text { brass }\end{array}$ & & Chelex 100 & Zincon & 70 & $\begin{array}{l}\mathrm{Cu}, 800 \\
\mathrm{Zn}, 350\end{array}$ & [18] \\
\hline
\end{tabular}

SPE, solid phase extraction; LOD, limit of detection; Ref., Reference; SIA, sequential injection analysis; PIM, polymer inclusion membrane; PAR, 4-(2-pyridylazo)resorcinol; PAN, 1-(2-pyridilazo)-2-naphtol; $\mu$ SI-LOV, micro sequential injection-lab-on-valve; SIC, sequential injection chromatography; MSFIA, multi-syringe injection analysis; BIS-FIA, bead injection spectrometry-flow injection analysis; FIA, flow injection analysis. 
The use of PAR as chromogenic reagent, instead of other reagents used by other authors (e.g., dithizone and PAN) [9,13], displays some advantages: PAR is considered a non-hazardous substance, unlike dithizone that is considered an eye and skin irritant according to European regulations (EC) [25]. PAR is also a water-soluble reagent and thus does not need the use of organic solvents in its preparation.

Overall, with the developed flow system, it is possible to attain in about 10 min the determination of copper(II) and zinc(II) individual content in natural waters, involving relatively low cost and portable equipment and minimizing the consumption of reagents.

Supplementary Materials: The following are available online. Figure S1: Spectra of the colour metal complexes with PAR (A) and PAN (B); spectra of the blank (reagent in milliQ water) (blue lines), $\mathrm{Cu}(\mathrm{II})-\mathrm{PAR} / \mathrm{PAN}$ complex (yellow lines) and $\mathrm{Zn}(\mathrm{II})-\mathrm{PAR} / \mathrm{PAN}$ complex (green lines); PAR/PAN concentration of $0.1 \mathrm{mmol} \mathrm{L}^{-1}$; metal ion concentration of $0.5 \mu \mathrm{g} \mathrm{L}^{-1}$; and carbonate buffer $\left(0.6 \mathrm{mmol} \mathrm{L}^{-1}\right)$ solution at $\mathrm{pH}=10$, Figure S2: Study of the effect of the PIM column (A) and the Chelex column (B) on the calibration curves of zinc(II) and copper(II): (A) direct zinc(II) calibration curve without (blue) and with (orange) using a PIM; and (B) calibration curve with mixed standards of copper(II) and zinc(II) aspirated through the Chelex column (green) and without going through the Chelex column (grey) and calibration curve with zinc(II) standards with (yellow) and without (blue) using a Chelex column, Figure S3: Comparison of the results obtained with the newly developed SIA system and those obtained with a reference method (ICP-OES): (A) copper(II) determination; and (B) zinc(II) determination. The lines represent the linear relationship between the two methods.

Author Contributions: Conceptualization, R.B.R.M., S.D.K. and A.O.S.S.R.; methodology, T.C.F.R., C.F.C., M.I.G.S.A. and R.B.R.M.; validation, T.C.F.R.; formal analysis, T.C.F.R. and R.B.R.M.; investigation, T.C.F.R. and C.F.C.; resources, S.D.K. and A.O.S.S.R.; writing-original draft preparation, T.C.F.R.; writing-review and editing, M.I.G.S.A., R.B.R.M., S.D.K. and A.O.S.S.R.; supervision, M.I.G.S.A., R.B.R.M., S.D.K. and A.O.S.S.R.; project administration, S.D.K. and A.O.S.S.R.; and funding acquisition, S.D.K. and A.O.S.S.R. All authors have read and agreed to the published version of the manuscript.

Funding: This work was funded by FEDER through project reference POCI-01-0145-FEDER-031522 (Programa Operacional Competitividade e Internacionalização) and by National Funds from FCT (Fundação para a Ciência e Tecnologia); scientific collaboration from FCT projects PTDC/AAG-MAA/5887/2014 and UID/Multi/50016/2019 is also acknowledged. T.C.F.R. thanks FEDER and FCT for the grant PTDC/CTA-OHR/31522/2017_BI_1.

Conflicts of Interest: The authors declare no conflict of interest.

\section{References}

1. Carasek, E.; Merib, J. Membrane-Based Microextraction Techniques in Analytical Chemistry: A Review. Anal. Chim. Acta 2015, 880, 8-25. [CrossRef] [PubMed]

2. Camel, V. Solid Phase Extraction of Trace Elements. Spectrochim. Acta Part B At. Spectrosc. 2003, 58, 1177-1233. [CrossRef]

3. Calderilla, C.; Maya, F.; Leal, L.O.; Cerdà, V. Recent Advances in Flow-Based Automated Solid-Phase Extraction. TrAC Trends Anal. Chem. 2018, 108, 370-380. [CrossRef]

4. Płotka-Wasylka, J.; Szczepańska, N.; De La Guardia, M.; Namieśnik, J. Miniaturized Solid-Phase Extraction Techniques. TrAC Trends Anal. Chem. 2015, 73, 19-38. [CrossRef]

5. Ribas, T.C.; Tóth, I.V.; Rangel, A.O. A Solid Phase Extraction Flow Injection Spectrophotometric Method for the Zinc Determination in Plants. Microchem. J. 2017, 130, 366-370. [CrossRef]

6. Nghiem, L.D.; Mornane, P.; Potter, I.D.; Perera, J.M.; Cattrall, R.W.; Kolev, S.D. Extraction and Transport of Metal Ions and Small Organic Compounds Using Polymer Inclusion Membranes (PIMs). J. Membr. Sci. 2006, 281, 7-41. [CrossRef]

7. Almeida, M.I.G.S.; Cattrall, R.W.; Kolev, S.D. Polymer Inclusion Membranes (PIMs) in Chemical Analysis-A Review. Anal. Chim. Acta 2017, 987, 1-14. [CrossRef]

8. Ohyoshi, E. Relative Stabilities of Metal Complexes of 4-(2-pyridylazo)resorcinol and 4-(2-thiazolylazo) resorcinol. Polyhedron 1986, 5, 1165-1170. [CrossRef]

9. Paluch, J.; Mesquita, R.B.; Cerdà, V.; Kozak, J.; Wieczorek, M.; Rangel, A.O. Sequential Injection System With in-Line Solid Phase Extraction and Soil Mini-Column for Determination of Zinc and Copper in Soil Leachates. Talanta 2018, 185, 316-323. [CrossRef]

10. Almeida, M.I.G.; Cattrall, R.W.; Kolev, S.D. Recent Trends in Extraction and Transport of Metal Ions Using Polymer Inclusion Membranes (PIMs). J. Membr. Sci. 2012, 9-23. [CrossRef] 
11. Kuswandi, B.; Nitti, F.; Almeida, M.I.G.S.; Kolev, S.D. Water Monitoring Using Polymer Inclusion Membranes: A Review. Environ. Chem. Lett. 2019, 18, 129-150. [CrossRef]

12. Kolev, S.D.; Baba, Y.; Cattrall, R.W.; Tasaki, T.; Pereira, N.; Perera, J.M.; Stevens, G.W. Solid Phase Extraction of Zinc(II) Using a PVC-Based Polymer Inclusion Membrane with Di(2-ethylhexyl)phosphoric Acid (D2EHPA) as the Carrier. Talanta 2009, 78, 795-799. [CrossRef] [PubMed]

13. Santos, I.C.; Mesquita, R.B.; Rangel, A.O. Micro Solid Phase Spectrophotometry in a Sequential Injection Lab-on-Valve Platform for Cadmium, Zinc, and Copper Determination in Freshwaters. Anal. Chim. Acta 2015, 891, 171-178. [CrossRef] [PubMed]

14. Páscoa, R.; Tóth, I.V.; Rangel, A.O. Spectrophotometric Determination of Zinc and Copper in a Multi-Syringe Flow Injection Analysis System Using a Liquid Waveguide Capillary Cell: Application to Natural Waters. Talanta 2011, 84, 1267-1272. [CrossRef]

15. Shpigun, L.K.; Shushenachev, Y.V.; Kamilova, P.M. Simultaneous Spectrophotometric Determination of copper(II) and zinc(II) Based on Their Kinetic Separation in Flow-Injection Systems. J. Anal. Chem. 2007, 62, 623-631. [CrossRef]

16. Ruedas-Rama, M.J.; Ruiz-Medina, A.; Molina-Díaz, A. Resolution of Biparametric Mixtures Using Bead Injection Spectroscopic Flow-through Renewable Surface Sensors. Anal. Sci. 2005, 21, 1079-1084. [CrossRef]

17. Morais, I.P.; Souto, M.R.S.; Rangel, A.O.S.S. A Double-Line Sequential Injection System for the Spectrophotometric Determination of Copper, Iron, Manganese, and Zinc in Waters. J. AOAC Int. 2005, 88, 639-644. [CrossRef]

18. Richter, P.; Toral, M.I.; Fuenzalida, E.; Tapia, A.E. Flow Injection Photometric Determination of Zinc and Copper With Zincon Based on the Variation of the Stability of the Complexes with PH. Analyst 1997, 122, 1045-1048. [CrossRef]

19. Horstkotte, B.; Jarošová, P.; Chocholouš, P.; Sklenářová, H.; Solich, P. Sequential Injection Chromatography With Post-Column reaction/Derivatization for the Determination of Transition Metal Cations in Natural Water Samples. Talanta 2015, 136, 75-83. [CrossRef]

20. Standard Methods for the Examination of Water and Wastewater, 19th ed.; American Public Health Association: Washington, DC, USA, 1998.

21. Nomenclature, symbols, units and their usage in spectrochemical analysis-II. Int. Union Pure Appl. Chem. 1976, 45, 101-103. [CrossRef]

22. Currie, L.A. Nomenclature in Evaluation of Analytical Methods Including Detection and Quantification Capabilities (IUPAC Recommendations 1995). Pure Appl. Chem. 1995, 67, 1699-1723. [CrossRef]

23. Miller, J.N.; Miller, J. Statistics and Chemometrics for Analytical Chemistry, 6th ed.; Pearson Education Limited: Harlow, UK, 2010.

24. Zagatto, E.A.G.; Arruda, M.; Jacintho, A.; Mattos, I. Compensation of the Schlieren Effect in Flow-Injection Analysis by Using Dual-Wavelength Spectrophotometry. Anal. Chim. Acta 1990, 234, 153-160. [CrossRef]

25. Guidance on Labelling and Packaging in Accordance With Regulation (EC) No 1272/2008_Publications Office of the EU. Available online: https://echa.europa.eu/home (accessed on 28 October 2020).

Publisher's Note: MDPI stays neutral with regard to jurisdictional claims in published maps and institutional affiliations.

(C) 2020 by the authors. Licensee MDPI, Basel, Switzerland. This article is an open access article distributed under the terms and conditions of the Creative Commons Attribution (CC BY) license (http://creativecommons.org/licenses/by/4.0/). 